\title{
Donor haplotype B of NK KIR receptor reduces the relapse risk in HLA-identical sibling hematopoietic stem cell transplantation of AML patients
}

\section{Ulla Impola ${ }^{1}$, Hannu Turpeinen ${ }^{2}$, Noora Alakulppi ${ }^{1}$, Tiina Linjama ${ }^{1}$, Liisa Volin ${ }^{3}$, Riitta Niittyvuopio ${ }^{3}$, Jukka Partanen ${ }^{1}$ and Satu Koskela ${ }^{1}$ *}

${ }^{1}$ FRC Blood Service, Research and Development, Helsinki, Finland

2 Institute of Biosciences and Medical Technology (BioMediTech), University of Tampere, Tampere, Finland

${ }^{3}$ Division of Hematology, Helsinki University Central Hospital, Helsinki, Finland

\section{Edited by:}

Antoine Toubert, Université Paris

Diderot, France

\section{Reviewed by:}

Stanislaw Stepkowski, University of Toledo College of Medicine, USA

Pascale Loiseau, Hopital Saint-Louis AP-HP, France

*Correspondence:

Satu Koskela, FRC Blood Service, Kivihaantie 7, Helsinki 00310, Finland e-mail: satu.koskela@veripalvelu.fi
Successful allogeneic hematopoietic stem cell transplantation (HSCT) depends not only on good HLA match but also on T-cell mediated graft-versus-leukemia (GVL) effect. Natural killer (NK) cells are able to kill malignant cells by receiving activation signal from the killer-cell immunoglobulin-like receptors (KIR) recognizing HLA molecules on a cancer cell. It has been recently reported that the risk of relapse in allogeneic hematopoietic stem cell transplantation (HSCT) is reduced in acute myeloid leukemia (AML) patients whose donors have several activating KIR genes or KIR B-motifs in unrelated donor setting, obviously due to enhanced GvL effect by NK cells. We studied the effect on relapse rate of donor KIR haplotypes in the HLA-identical adult sibling HSCT, done in a single center, in Helsinki University Central Hospital, Helsinki, Finland. Altogether, 134 patients with 6 different diagnoses were identified. Their donors were KIR genotyped using the Luminex and the SSP techniques. The clinical endpoint, that is, occurrence of relapse, was compared with the presence or absence of single KIR genes. Also, time from transplantation to relapse was analyzed. The patients with AML whose donors have KIR2DL2 or KIR2DS2 had statistically significantly longer relapse-free survival $(P=0.015)$. Our data support previous reports that donors with KIR B-haplotype defining genes have a lower occurrence of relapse in HSCT of AML patients. Determination of donor KIR haplotypes could be a useful addition for a risk assessment of HSCT especially in AML patients.

Keywords: NK cells, KIR, HLA, graft versus tumor effect, transplantation immunology

\section{INTRODUCTION}

Allogeneic hematopoietic stem cell transplantation (HSCT) is an established curative treatment for many hematological malignancies. The outcome of HSCT is strongly influenced by the genetic differences between donor/recipient pairs (1). Genetic similarity or identity in the HLA genes in the major histocompatibility complex on chromosome 6, affects the incidence of graft-versushost disease (GvHD), the major complication of HSCT. Successful allogeneic HSCT, however, depends also on T-cell mediated graft-versus-leukemia $(\mathrm{GvL})$ effect, in which donor-derived $\mathrm{T}$ cells clear the remaining leukemic cells in patient. In addition to alloreactive $\mathrm{T}$ cells, donor-derived natural killer (NK) cells, are able to kill these malignant or virus-infected cells in the patient. NK cells might therefore have a crucial role in relapse prevention by destroying remaining acute myeloblastic leukemia cells $(2,3)$.

Natural killer cells are regulated by their surface receptors, which have either activating or inhibitory function by interacting with MHC class I molecules, i.e., group 1 and group 2 HLA-C alleles and Bw4 alleles, present on normal cell surface. Activation occur when the NK cell receives a signal from the killer-cell immunoglobulin-like receptors (KIR) that recognize affected or tumor cell lacking the normal HLA structures on its surface. The ratio of activating and inhibitory receptors on the NK cell surface determines how easily NK cell is activated (4).

Killer-cell immunoglobulin-like receptors are genetically highly polymorphic and are expressed in a stochastic manner. The HLA and KIR genes are located in the different chromosomes and are therefore inherited independently. Consequently, many people may have activating and/or inhibitory KIR genes for which they do not have the HLA ligands. Only minority of HLA-matched donor-patient pairs have the same KIR haplotypes and in case of HLA-matched siblings, KIR haplotype identity occurs in $25 \%$ of donor-patient pairs (5). Seventeen of the KIR genes can be categorized for the inhibitory (KIR A-haplotype) or the activating haplotypes (KIR B haplotype) based on their gene content (6). These haplotypes can be further divided as telomeric and centromeric parts, which contain either A- or B-motifs according to the presence or absence of A- or B-haplotype defining KIR genes (Figure 1).

The first evidence of the role of the KIR genes in HSCT came from haploidentical transplantation studies by Ruggeri et al. They showed that acute myeloid leukemia (AML) patients benefit from the KIR-ligand mismatch due to the "missing self" 


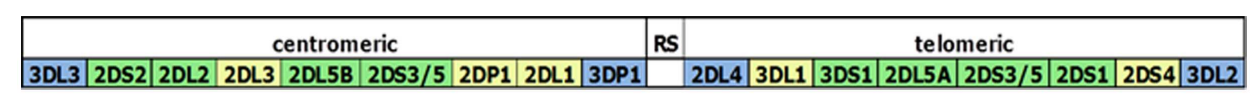

FIGURE 1 |The KIR locus in chromosome 19 is part of the leukocyte receptor complex (LRC) region and is composed of centromeric and telomeric parts. The two parts are separated by a recombination site (RS) sequence. B-haplotype defining genes are depicted in green color, and A-haplotype defining genes are depicted in yellow color. The framework genes that are present in each haplotype are blue.

Table 1 | Altogether, 134 patients with 6 diagnoses were included in statistical analysis.

\begin{tabular}{|c|c|c|c|c|c|c|c|}
\hline \multirow[t]{2}{*}{ Diagnosis } & \multirow[t]{2}{*}{ No. of patients } & \multirow[t]{2}{*}{ Relapse } & \multirow[t]{2}{*}{ aGvHD grade II-IV } & \multicolumn{2}{|c|}{ Graft type } & \multicolumn{2}{|c|}{ Disease status } \\
\hline & & & & PB & BM & Good prognosis & Bad prognosis \\
\hline AML & 47 & 14 & 11 & 15 & 32 & 33 & 14 \\
\hline MDS & 16 & 5 & 2 & 3 & 13 & 6 & 10 \\
\hline $\mathrm{CML}$ & 31 & 9 & 10 & 7 & 24 & 20 & 11 \\
\hline $\mathrm{CLL} / \mathrm{NHL}$ & 13 & 1 & 2 & 5 & 8 & 9 & 4 \\
\hline$A L L$ & 27 & 8 & 5 & 7 & 20 & 19 & 8 \\
\hline Total & 134 & 37 & 30 & 37 & 97 & 87 & 47 \\
\hline
\end{tabular}

Diagnoses were: acute myeloid leukemia (AML), myelodysplastic syndrome (MDS), chronic myeloid leukemia (CML), chronic lymphoid leukemia (CLL), non-Hodgkin lymphoma (NHL), acute lymphoid leukemia ALL. Graft types used were peripheral blood (PB) or bone marrow (BM).

phenomenon $(7,8)$. In addition, there is evidence that the risk of relapse is reduced in those AML patients whose donors have several activating KIR genes or KIR-B gene-motifs in unrelated donor (URD) HSCT $(9,10)$. However, there are also some conflicting results (10-12). Clinical benefits have been speculated to be gained in settings, where donor NK cells have at least one inhibitory KIR gene for which they lack the specific HLA class I ligand (13).

In the present study, we looked if activating KIR genes in the HLA-matched related donors (RD) have any effect on relapse incidence or rate in transplanted patients. Altogether, 134 HLAmatched related sibling pairs were included in this study. We further focused the AML patients and their donors as the number of patients with other diagnosis was low and the most promising results about KIR genes or KIR ligands have been observed in the AML patients. The clinical data were compared with the presence or absence of single KIR genes and with the KIR B-content score. Our results support previous findings that donors with KIR Bhaplotype defining genes contribute the GvL effect resulting in a lower relapse incidence in AML patients after HSCT.

\section{MATERIALS AND METHODS \\ PATIENTS}

Altogether, 134 adult patients who had undergone related donor HSCT and their donors were included into this study. Patient cohort consisted of 6 different diagnoses; 47 patients had AML (Table 1). Transplantations were performed in Helsinki University Central Hospital Hematology Clinic, Helsinki, Finland, during 1993-2004. The set of patients is basically identical to that described in our previous studies $(14,15)$. Informed consent was obtained from all subjects and the study protocol was approved by the local Ethical Review Board of the Helsinki University Hospital, Helsinki, Finland.

\section{GENOTYPING}

\section{HLA}

All patients and donors were typed for HLA-A, -B, -C, -DRB1, and -DQB1 using EFI accredited typing methods in routine typing of the transplantation candidates either by serological method (Lymphotype HLA-AB and Lymphotype HLA-DR-DQ, Bio-Rad Medical Diagnostics, Dreieich, Germany) or by using PCR-based typing methods using the LIPA HLA-C reverse dot blot kit (Innogenetics Group, Gent, Belgium), or the Pel Freez HLA-C SSP kits (Dynal Biotech LLC, Oslo, Norway), or the LABType SSO HLA typing Test (One Lambda Inc., 21001 Kittridge Street, Canoga Park, CA 91303-2801, USA). Only 10/10 HLA-matched siblings were included in the study.

\section{KIR genotyping}

Samples were whole genome amplified by using the GenomiPhi V2 DNA Amplification Kit (GE Healthcare UK Ltd., Chalfont, Bucks, UK). The amplified DNA samples from the donors were KIR genotyped by using the LABType SSO KIR typing Test (One Lambda Inc., 21001 Kittridge Street, Canoga Park, CA 91303-2801, USA) according to the manufacturer's instructions or in some cases by using Olerup SSP ${ }^{\circledR}$ KIR Genotyping kit (Olerup SSP AB, Stockholm, Sweden).

\section{STATISTICAL ANALYSIS}

The incidence of the relapse was compared with the presence or absence of single KIR genes and with the KIR B-content score (IPD KIR sequence database, EBI, B-content calculator) within each diagnosis category. The Log-rank (Peto) and the Wilcoxon tests were used for the statistical analysis by using the StatsDirect software (StatsDirect Ltd. 9 Bonville Chase, Altrincham Cheshire, UK).

Also, time to relapse was analyzed in survival analyses using Kaplan-Meier and Cox regression analyses. 


\section{RESULTS}

In this study, we looked if activating KIR genes in the HLAmatched $\mathrm{RD}$ have any effect on relapse rate in transplanted patients. The KIR-B-content score and single KIR genes were evaluated against relapse both in the whole patient cohort and within each diagnosis category.

Statistical significance for better relapse-free survival (log-rank $p$-value of 0.059 in Kaplan-Meier) was observed for AML patients whose donor had KIR2DS2 or KIR2DL2 (Figure 2). This effect was even strengthened when other factors affecting relapse $(\mathrm{a} / \mathrm{cGvHD}$,

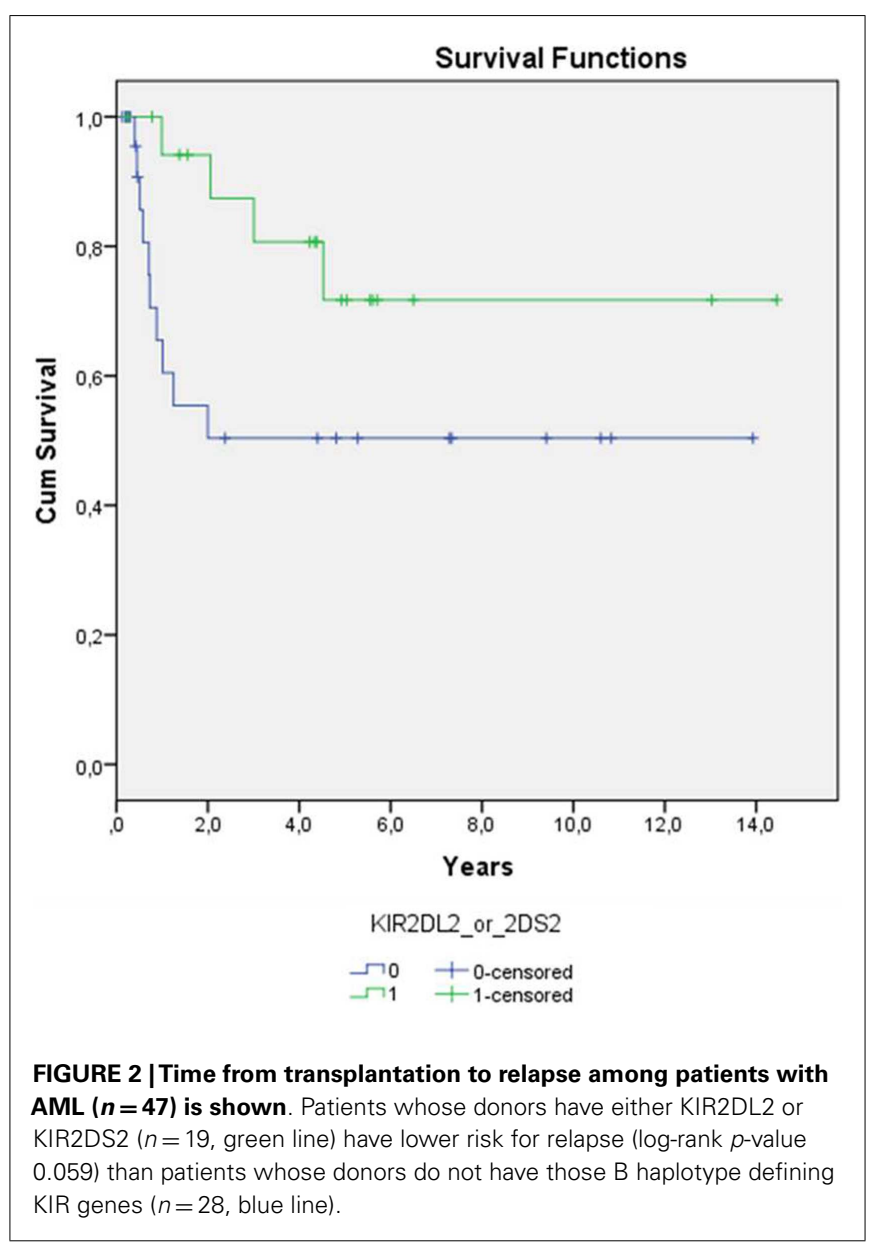

graft type, disease status, GvHD prevention) were included in the analyses (Cox regression $p=0.015$, Table 2 ). Graft type and disease status also had an effect on the relapse rate as expected $(p=0.050$ and 0.014 , respectively). Longer relapse-free survival was observed in the patients receiving peripheral blood stem cells compared to the patients receiving bone marrow and also in the patients with good prognosis compared to the patients with bad prognosis. No significant $P$-values were observed for other KIR genes or diagnoses.

Statistical significance was not reached when the donor KIR-Bcontent score was evaluated in AML patients, but a trend between high KIR-B-content score and low relapse rate could be seen (Log-rank $P=0.39$, Wilcoxon $P=0.39$, data not shown).

If all the patients with different diagnoses were included in the tests, the statistical significance or trend was lost both in single gene analysis and B-content score analysis. The frequencies of KIR genes in the donors were similar to those reported earlier (16).

\section{DISCUSSION}

HLA matching is a prerequisite for the successful HSCT and is the most important factor that is taken into account before transplantation. There is increasing evidence that also other genes of the genome like KIR genes and minor histocompatibility antigens (mHAs) (17-19) contribute to the outcome. The effect of the KIR genes has been studied in different settings where either related or URDs were used for either T-cell depleted or repleted patients (7, 9, 20-22).

Ruggeri et al. demonstrated an advantageous effect on the survival of the AML patients in the KIR-ligand mismatched haploidentical transplantation in which the donor NK cell recognition of the missing self on the recipient targets is associated with the GvL effect. The positive effect on the survival of the AML patients was also observed in URD transplantations when the KIR genes were grouped according to the number of the activating and inhibitory KIR genes. Donors with more activating KIR genes (KIR B-haplotype) had more GvL effect than the donors with inhibitory KIR genes (KIR A-haplotype). The greater the KIR B-score was, the less relapses were observed (9). As there are as many as $17 \mathrm{KIR}$ genes that form different haplotypes and as each of them has the different ligand specificity, the mechanism how these parameters act together in a beneficial manner must be complex.

Table 2 | Multivariate Cox regression analyses of relapse rate in AML patients.

\begin{tabular}{|c|c|c|c|c|c|c|c|c|}
\hline & \multirow[t]{2}{*}{ B } & \multirow[t]{2}{*}{ SE } & \multirow[t]{2}{*}{ Wald } & \multirow[t]{2}{*}{ df } & \multirow[t]{2}{*}{ Sig. } & \multirow[t]{2}{*}{$\operatorname{Exp}(B)$} & \multicolumn{2}{|c|}{$95.0 \% \mathrm{Cl}$ for $\operatorname{Exp}(\mathrm{B})$} \\
\hline & & & & & & & Lower & Upper \\
\hline aGvHD & 0.141 & 0.859 & 0.027 & 1 & 0.870 & 1.151 & 0.214 & 6.196 \\
\hline$c G v H D$ & -0.005 & 0.117 & 0.002 & 1 & 0.968 & 0.995 & 0.791 & 1.253 \\
\hline Graft_type & 1.718 & 0.878 & 3.831 & 1 & 0.050 & 5.575 & 0.998 & 31.150 \\
\hline Disease status & 2.299 & 0.937 & 6.022 & 1 & 0.014 & 9.968 & 1.589 & 62.546 \\
\hline
\end{tabular}

Presence of donor KIR2DL2 and KIR2DS2 as well as good prognosis and using bone marrow as stem cell source has a beneficial influence on patients' relapse-free survival. 
In this study, donor KIR2DS2 and KIR2DL2 that are KIR B-haplotype defining genes, were associated with the longer relapse-free survival of AML patients. It seems that the donors with KIR B-haplotype defining genes may protect patients against relapse especially in myeloblastic leukemias compared to the donors without or with only few activating KIR genes. The enhanced GvL effect was even strengthened when other relapseaffecting factors such as graft type and disease status were included in multivariate analyses. As a/cGvHD or GvHD prevention did not seem to affect the incidence of relapse, it is possible that biological agents that are involved in these phenomena are different from the GvL. These results together with Cooley et al. suggest that selecting donors with KIR-B haplotype defining genes may be beneficial in different transplantation settings since our study comprised fully matched RD and Cooley et al. studied registry donors. In addition, there is evidence that donors with several activating KIR genes protect patients from the CMV activation after HSCT (23-25) although in some studies no beneficial effect was observed $(10,26)$.

It must be noted that the $P$ values in our study are influenced by the small sample size as 134 patients represented 6 different diagnoses and several different KIR genes exist in human genome and therefore studies with larger cohort are needed. Our results support, however, the observation that selecting the donors with more KIR B-haplotype defining genes may lower the risk of relapse in HSCT. Taking the KIR genotype or KIR-ligand mismatch into account in donor selection may have a beneficial effect on the patients' survival and at least is a valuable tool in risk assessment in any transplantation setting. However, the downside of the selecting donors with high KIR B-content score and/or appropriate KIR ligand is the increased incidence of the GvHD, the life threatening condition $(27,28)$.

\section{AUTHOR CONTRIBUTIONS}

Satu Koskela, Ulla Impola, Hannu Turpeinen, Noora Alakulppi, Tiina Linjama, and Jukka Partanen designed this study, performed the experimental design and data analysis. They also provided their intellectual content for the study. Liisa Volin and Riitta Niittyvuopio provided patient cohort and clinical data integration. Satu Koskela, Ulla Impola, Hannu Turpeinen, and Jukka Partanen wrote the manuscript.

\section{ACKNOWLEDGMENTS}

The study was supported by the Finnish Government EVO fund. We thank Lotta Andersson and Liisa Partanen for their technical expertise. We thank James Robinson for his help in KIR batch analysis.

\section{REFERENCES}

1. Warren ED, Zhang XC, Li S, Fan W, Storer BE, Chien JW, et al. Effect of MHC and non-MHC donor/recipient genetic disparity on the outcome of allogeneic HCT. Blood (2012) 120:2796-806. doi:10.1182/blood-2012-04-347286

2. Foley B, Felices M, Cichocki F, Cooley S, Verneris MR, Miller JS. The biology of NK cells and their receptors affects clinical outcomes after hematopoietic cell transplantation (HCT). Immunol Rev (2014) 258:45-63. doi:10.1111/imr. 12157

3. Velardi A. Role of KIRs and KIR ligands in hematopoietic transplantation. Curr Opin Immunol (2008) 20:581-7. doi:10.1016/j.coi.2008.07.004
4. Moretta L, Bottino C, Cantoni C, Mingari MC, Moretta A. Human natural killer cell function and receptors. Curr Opin Pharmacol (2001) 1(4):387-91. doi:10.1016/S1471-4892(01)00067-4

5. Shilling HG, Young N, Guethlein LA, Cheng NW, Gardiner CM, Tyan D, et al. Genetic control of human NK cell repertoire. J Immunol (2002) 169(1):239-47. doi:10.4049/jimmunol.169.1.239

6. Hsu KC, Liu XR, Selvakumar A, Mickelson E, O’Reilly RJ, Dupont B. Killer Iglike receptor haplotype analysis by gene content: evidence for genomic diversity with a minimum of six basic framework haplotypes, each with multiple subsets. J Immunol (2002) 169:5118-29. doi:10.4049/jimmunol.169.9.5118

7. Ruggeri L, Capanni M, Urbani E, Perruccio K, Shlomchik WD, Tosti A, et al. Effectiveness of donor natural killer cell alloreactivity in mismatched hematopoietic transplants. Science (2002) 295:2097. doi:10.1126/ science. 1068440

8. Stern M, Paulussen M, Rischewski J, Tichelli A, Gratwohl A. Missing ligand model in autologous stem cell transplantation. Br J Cancer (2008) 98:852-3. doi:10.1038/sj.bjc.6604153

9. Cooley S, Weisdorf DJ, Guethlein LA, Klein JP, Wang T, Le CT, et al. Donor selection for natural killer cell receptor genes leads to superior survival after unrelated transplantation for acute myelogenous leukemia. Blood (2010) 116:2411-9. doi:10.1182/blood-2010-05-283051

10. Kröger N, Binder T, Zabelina T, Wolschke C, Schieder H, Renges H, et al. Low number of donor activating killer immunoglobulin-like receptors (KIR) genes but not KIR-ligand mismatch prevents relapse and improves disease-free survival in leukemia patients after in vivo T-cell depleted unrelated stem cell transplantation. Transplantation (2006) 82:1024-30. doi:10.1097/01.tp.0000235859. 24513.43

11. Davies SM, Ruggieri L, DeFor T, John E, Wagner JE, Weisdorf DJ, et al. Evaluation of KIR ligand incompatibility in mismatched unrelated donor hematopoietic transplants. Blood (2002) 100:3825-7. doi:10.1182/blood-2002-04-1197

12. Sivula J, Volin L, Porkka K, Vettenranta K, Itälä M, Partanen J, et al. Killer-cell immunoglobulin-like receptor ligand compatibility in the outcome of Finnish unrelated donor hematopoietic stem cell transplantation. Transpl Immunol (2007) 18:62-6. doi:10.1016/j.trim.2007.03.006

13. Dupont B, Hsu K. Inhibitory killer Ig-like receptor genes and human leukocyte antigen class I ligands in haematopoietic stem cell transplantation. Curr Opin Immunol (2004) 16:634-43. doi:10.1016/j.coi.2004.07.013

14. Sivula J, Turpeinen H, Volin L, Partanen J. Association of IL-10 and IL-10R $\beta$ gene polymorphisms with graft-versus-host disease after haematopoietic stem cell transplantation from an HLA-identical sibling donor. BMC Immunol (2009) 10:24. doi:10.1186/1471-2172-10-24

15. Turpeinen H, Volin L, Nikkinen L, Ojala P, Palotie A, Saarela J, et al. Genetic similarity of chromosome 6 between patients receiving hematopoietic stem cell transplantation and HLA matched sibling donors. Haematologica (2009) 94:528-35. doi:10.3324/haematol.2008.000919

16. Denis L, Sivula J, Gourraud P-A, Kerdudou N, Chout R, Ricard C, et al. Genetic diversity of KIR natural killer cell markers in populations from France, Guadeloupe, Finland, Senegal and Réunion. Tissue Antigens (2005) 66:267-76. doi:10.1111/j.1399-0039.2005.00473.x

17. Cooley S, Trachtenberg E, Bergemann TL, Saeteurn K, Klein J, Le CT, et al. Donors with group B KIR haplotypes improve relapse-free survival after unrelated hematopoietic cell transplantation for acute myelogenous leukemia. Blood (2009) 113:726-32. doi:10.1182/blood-2008-07-171926

18. Spierings E, Kim YH, Hendriks M, Borst E, Sergeant R, Canossi A, et al. Multicenter analyses demonstrate significant clinical effects of minor histocompatibility antigens on GvHD and GvL after HLA-matched related and unrelated hematopoietic stem cell transplantation. Biol Blood Marrow Transplant (2013) 19(8):1244-53. doi:10.1016/j.bbmt.2013.06.001

19. McCarroll SA, Bradner JE, Turpeinen H, Volin L, Martin PJ, Chilewski SD, et al. Donor-recipient mismatch for common gene deletion polymorphisms in graftversus-host disease. Nat Genet (2009) 41(12):1341-5. doi:10.1038/ng.490

20. Ruggeri L, Mancusi A, Capanni M, Urbani E, Carotti A, Aloisi T, et al. Donor natural killer cell allorecognition of missing self in haploidentical hematopoietic transplantation for acute myeloid leukemia: challenging its predictive value. Blood (2007) 110:433-40. doi:10.1182/blood-2006-07-038687

21. Stringaris K, Adams S, Marcela Uribe M, Eniafe R, Wu CO, Savani BN, et al. Donor KIR genes 2DL5A, 2DS1 and 3DS1 are associated with a reduced rate of leukemia relapse after HLA-Identical sibling stem cell transplantation for acute 
myeloid leukemia but not other hematologic malignancies. Biol Blood Marrow Transplant (2010) 16:1257-64. doi:10.1016/j.bbmt.2010.03.004

22. Symons HJ, Leffell MS, Rossiter ND, Zahurak M, Jones RJ, Fuchs EJ. Improved survival with inhibitory killer immunoglobulin receptor (KIR) gene mismatches and KIR haplotype B donors after nonmyeloablative, HLA-haploidentical. Bone Marrow Transplant (2010) 16:533-42. doi:10.1016/j.bbmt.2009.11.022

23. Sobecks RM, Askar M, Thomas D, Rybicki L, Kalayci M, Dean R, et al. Cytomegalovirus reactivation after matched sibling donor reduced-intensity conditioning allogeneic hematopoietic stem cell transplant correlates with donor killer immunoglobulin-like receptor genotype. Exp Clin Transplant (2011) 9:7-13.

24. Zaia JA, Sun JY, Gallez-Hawkins GM, Thao L, Oki A, Lacey SF, et al. The effect of single and combined activating killer immunoglobulin-like receptor genotypes on cytomegalovirus infection and immunity after hematopoietic cell transplantation. Biol Blood Marrow Transplant (2009) 15:315-25. doi:10.1016/j.bbmt.2008.11.030

25. Cook M, Briggs D, Craddock C, Mahendra P, Milligan D, Fegan C, et al. Donor KIR genotype has a major influence on the rate of cytomegalovirus reactivation following T-cell replete stem cell transplantation. Blood (2006) 107:1230-2. doi:10.1182/blood-2005-03-1039

26. Tomblyn M, Young J-AH, Michael D, Haagenson MD, Klein JP, Trachtenberg EA, et al. Decreased infections in recipients of unrelated donor hematopoietic cell transplantation from donors with an activating KIR genotype. Biol Blood Marrow Transplant (2010) 16:1155-61. doi:10.1016/j.bbmt.2010.02.024

27. McQueen KL, Dorighi KM, Guethlein LA, Wong R, Sanjanwala B, Parham P. Donor-recipient combinations of group A and B KIR haplotypes and HLA class I ligand affect the outcome of HLA-matched, sibling donor hematopoietic cell transplantation. Hum Immunol (2007) 68:309-23. doi:10.1016/j.humimm. 2007.01.01928

28. Gagne K, Brizard G, Gueglio B, Milpied N, Herry F, Bonneville F, et al. Relevance of KIR gene polymorphisms in bone marrow transplantation outcome. Hum Immunol (2002) 63:271-80. doi:10.1016/S0198-8859(02)00373-7

Conflict of Interest Statement: The authors declare that the research was conducted in the absence of any commercial or financial relationships that could be construed as a potential conflict of interest.

Received: 31 March 2014; accepted: 07 August 2014; published online: 25 August 2014. Citation: Impola U, Turpeinen H, Alakulppi N, Linjama T, Volin L, Nitttyvuopio R, Partanen J and Koskela S (2014) Donor haplotype B of NK KIR receptor reduces the relapse risk in HLA-identical sibling hematopoietic stem cell transplantation of AML patients. Front. Immunol. 5:405. doi: 10.3389/fimmu.2014.00405

This article was submitted to Alloimmunity and Transplantation, a section of the journal Frontiers in Immunology.

Copyright $\odot 2014$ Impola, Turpeinen, Alakulppi, Linjama, Volin, Niittyvuopio, Partanen and Koskela. This is an open-access article distributed under the terms of the Creative Commons Attribution License (CC BY). The use, distribution or reproduction in other forums is permitted, provided the original author(s) or licensor are credited and that the original publication in this journal is cited, in accordance with accepted academic practice. No use, distribution or reproduction is permitted which does not comply with these terms. 